\title{
Diabetic foot ulcer: risk factors among patients of a secondary healthcare facility in south west Nigeria
}

\author{
Olatunde Odusan ${ }^{1}$, Olorunfemi E. Amoran ${ }^{2}$, and Oluwatoyin Salami ${ }^{3}$
}

Ghana Med J 2018; 52(4): 222-227 doi: http://dx.doi.org/10.4314/gmj.v52i4.9

\author{
${ }^{1}$ Department of Medicine, ${ }^{2}$ Department of Community Medicine and Primary Care; Obafemi Awolowo College \\ of Health Sciences, OOUTH, Sagamu, Nigeria \\ ${ }^{3}$ General Hospital, Marina. Lagos, Nigeria
}

Corresponding author: Olatunde Odusan

E-mail: tunsan2001@yahoo.com

Conflict of interest: None declared

\section{SUMMARY}

Background: Diabetic foot ulcer is a common long term complication of diabetes and the most common cause of non-traumatic amputation and prolonged hospitalization. These increases disease burden and further worsen quality of life.

Aim: This study evaluated exposure risk factors for foot ulcers among diabetics attending a secondary healthcare facility in Southwest Nigeria.

Methods: A case control study of exposure risk factors for diabetes foot ulcer (DFU) at General Hospital Marina Lagos. Using a structured interviewer administered questionnaire, information on foot care education, 24-hour dietary recall, medical history, anthropometric indices and social habits of participants were obtained and analyzed.

Results: There were 636 participants in this study (106 cases and 530 controls) with median age of $61.1 \pm 11.0$ years in both study groups and mostly females, $(75.5 \%$ in cases and $78.7 \%$ controls) with female to male ratio of $3: 1$. Majority, ( $83 \%$ in cases and $85 \%$ in controls) were in the low socioeconomic class and had lived with DM for more than 5years. Of the studied risk factors, lacking foot care education, diagnosis of visual impairment and hypertension, dietary intake of large proportion of carbohydrate meal at breakfast and dinner and obesity occured in significantly higher proportion of cases and controls and were associated with presence of DFU. $(p<0.05)$

Conclusions: Lack of foot care education, diagnosis of visual impairment, hypertension and poor dietary habit are associated with presence of DFU. Addressing these factors from point of diagnosis will go a long way in stemming the burden of diabetes foot ulcer.

Funding: Self-funding.

Keywords: Diabetes, foot ulcer, exposure risk factors, Southwest Nigeria.

\section{INTRODUCTION}

Diabetic foot Ulcer (DFU) is the most common chronic complication in persons with diabetes depending on disease duration and successful management.,2,3 About $25 \%$ of persons with diabetes mellitus (PWDM) will develop DFU while $5 \%$ to $15 \%$ will be treated for foot or leg amputation in a lifetime. ${ }^{4}$ The prevalence of DFU varies widely between $0.9-8.3 \%$ in Nigeria, $1.4 \%$ in United Kingdom, 4-10\% in United States of America and 18\% in Sudan. $2,3,5,7$ The North-West Diabetes Foot Care Study reported more than $2 \%$ of community-based diabetic patients develop foot ulcers every year. Consequently, a neuropathy disability score using the $10 \mathrm{~g}$ monofilament coupled with palpation of foot pulses was recommended as screening tools. ${ }^{8}$ Established risk factors for DFU include peripheral sensory neuropathy, peripheral arterial occlusive disease, structural foot deformity and unintentional or imperceptible trauma in the presence of insensate feet. ${ }^{2,9}$
This combination of ischaemia, peripheral vascular disease and loss of protective sensation set the stage for pressure necrosis, superficial cellulitis, ulceration, infection and chronic osteomyelitis that may finally culminate in gangrene. ${ }^{[10]}$ In a systematic review on predictive value of physical signs, diagnostic tests and patients' history related to DFU, there was paucity of evidence on predictive value of symptoms and medical history for DFU. This necessitates further research to establish factors from patients' history that may be associated with DFU. ${ }^{11,12}$

Diabetic foot ulcer, a major medical and socio-economic burden, contribute to high morbidity, prolonged hospitalisation and mortality. ${ }^{6}$ The economic burden of DFU is enormous with cost of treatment from ulcer to complete healing or amputation of between US\$102 and US\$3959. ${ }^{13,15}$ 
Foot structure is complex, combine bones, muscles, blood vessels and nerves, each of which may be affected by nutritional, defensive and repair mechanisms. Managing diabetic foot lesions is always a challenge to health professionals. Failure of foot ulcer treatment/healing may result from lack of health providers' understanding of the impact of treatment on patient's life while patients' understanding of the disease process and treatment recommendations for foot ulcer/amputation are viewed as extremely difficult and results in disruption and loss of independence. ${ }^{12,15,16}$

The International Diabetes Federation (IDF) reported that only 1 in 5 healthcare professionals receive postgraduate training in diabetes, while less than 1 in 2 people with diabetes and less than 1 in 4 family members of people with diabetes have access to diabetes education programme. This makes patient education a fundamental component of diabetes care that should be readily available and accessible. ${ }^{17}$ Primary prevention of DFU include foot care education, maintenance of good nutrition and glyco-metabolic control among others. ${ }^{18,19,20}$

Managing DM should include education on healthy lifestyle changes, regular exercise to control weight, quitting smoking, appropriate diet and treatment of glycaemic and lipid disorders. ${ }^{19,21,22}$ Shortage of trained diabetes care specialists, particularly at secondary health care facilities make patients seek treatment from other health care providers with little or no training in managing diabetes, diabetes foot lesion and also delay prompt referral. ${ }^{22}$ This study evaluated level of foot care education, past medical history, social and dietary habits with obesity as DFU risk factors among PLWD at a secondary health facility setting in Nigeria with aim to instituting appropriate measures of prevention to minimize DFU prevalence, burden and poor quality of life.

\section{METHODS}

\section{Study Design and Location}

This was a case control study of exposure risk factors associated with DFU among PLWD attending General Hospital Marina Lagos, a secondary healthcare facility in southwest Nigeria and conducted between April 2014 and May 2015. The study participants had lived with DM for at least 5 years and were being managed with diet and oral anti-diabetic medications. The study design excluded study of established clinical and laboratory risk factors for DFU.

\section{Sample size determination and technique}

A previous study from the same center on the prevalence and pattern of DFU yielded 106 diabetics with DFU, a prevalence of $17.3 \% .^{22}$ This population was adopted and for each, 5 PLWD but without DFU were consecutively recruited till 530 participants as controls was achieved yielding a total of 636 study participants. These had their data collated and analyzed.

\section{Data collection and instrument}

Participants' socio-demographic and anthropometric parameters were obtained from their hospital records. They were then interviewed using semi-structured questionnaire for information on foot care education, past medical history, 24 hour dietary recall, use of alcohol and smoking as well as presence of DFU.

\section{Pre-testing, data instrument and collection}

Details for pre-testing the questionnaire and data collection had been previously described. ${ }^{22}$

\section{Data management and analysis}

Data was organized and entered into Statistical Package for the Social Sciences (SPSS) version 17.0 software (IBM compatible). Categorical variables were compared using Chi- square test with logistic regression analysis for predictive values with level of statistical significance set at $\mathrm{p}<0.05$.

\section{Ethical consideration}

Ethical approval was obtained from Olabisi Onabanjo University Teaching Hospital Health Research and Ethics Committee (OOUTH-HREC). Approval to carry out the study was obtained from the authorities of the General Hospital Lagos while written or thumb printed informed consent was obtained from each study participant.

\section{RESULTS}

\section{Socio-demographic characteristics}

The mean age of study participants was $61.1 \pm 11.0$ years with age range of 30-70 years, more in 50-69 years bracket in cases than controls (69.8 and $58.1 \%, \mathrm{p}<0.05)$, more females, $[75.5 \%$ in cases and $78.7 \%$ in controls, (female to male ratio of 3:1] and mainly of Yoruba ethnic group $(81.1 \%$ and $85.3 \%$ respectively, $\mathrm{p}<0.05)$. Majority of respondents were housewives and semi-skilled workers $(83 \%$ vs $88.5 \%)$, with primary or secondary school education as highest educational qualifications (65.1\% vs $61.9 \%$ ) and earn less than $\mathrm{N} \mathrm{49,000.00} \mathrm{(about} 150$ US dollars) monthly (Table1).

Diabetes foot care education, lifestyle habits, medical history and diabetic foot ulcer

At the time of study, 21 (19.8\%) of cases had leg amputation from DFU. Most study participants $(90.2 \%$ of controls and $80.3 \%$ of cases) had never received foot care education, $80.4 \%$ of controls and $66.0 \%$ of cases were walking bare footed while $88.3 \%$ of controls and $81.1 \%$ of cases wore tight fitting shoes, a statistically significant difference. 


\section{Original Article}

Table 1 Demographic Characteristics of Study Participants

\begin{tabular}{|c|c|c|c|c|c|}
\hline $\begin{array}{l}\text { Characteris- } \\
\text { tics }\end{array}$ & $\begin{array}{l}\text { All } N=636 \\
(\%)\end{array}$ & $\begin{array}{l}\text { Cases } \\
n=106 \\
(\%)\end{array}$ & $\begin{array}{l}\text { Controls } \\
\mathbf{n}=\mathbf{5 3 0} \\
(\%)\end{array}$ & $\chi^{2}$ & p-value \\
\hline \multicolumn{6}{|l|}{ Age(Years) } \\
\hline 30-39 & $22(3.5)$ & $0(0.0)$ & $22(4.2)$ & & \\
\hline $40-49$ & $89(14.0)$ & $13(12.3)$ & $76(14.3)$ & 8.169 & $0.043^{*}$ \\
\hline $50-59$ & $156(24.5)$ & $24(22.6)$ & $132(24.9)$ & & \\
\hline $60-69$ & $226(35.5)$ & $50(47.2)$ & $176(33.2)$ & & \\
\hline 70+ & $143(22.5)$ & $19(17.9)$ & $124(23.4)$ & & \\
\hline $\begin{array}{ll}\begin{array}{l}\text { Mean } \\
\text { (years) }\end{array} & \text { Age } \\
\end{array}$ & & $61.1 \pm 11.0$ & $61.1 \pm 11.0$ & & \\
\hline \multicolumn{6}{|l|}{ Gender } \\
\hline Male & $139(21.6)$ & $26(24.5)$ & $113(21.3)$ & 0.532 & 0.466 \\
\hline Female & $497(78.1)$ & $80(75.5)$ & $417(78.7)$ & & \\
\hline \multicolumn{6}{|l|}{ Ethnicity } \\
\hline Yoruba & $538(84.6)$ & $86(81.1)$ & $452(85.3)$ & 10.180 & $0.006^{*}$ \\
\hline Igbo & $75(11.8)$ & $20(18.9)$ & $55(10.4)$ & & \\
\hline Hausa & $23(0.36)$ & $0(0.0)$ & $23(4.3)$ & & \\
\hline \multicolumn{6}{|l|}{ Occupation } \\
\hline $\begin{array}{l}\text { Unem- } \\
\text { ployed/house } \\
\text { wife }\end{array}$ & $218(34.3)$ & $27(25.5)$ & 191(36.0) & 5.436 & 0.066 \\
\hline Semi-skilled & $339(53.3)$ & $61(57.5)$ & $278(52.5)$ & & \\
\hline Civil servant & $79(12.4)$ & $18(17.0)$ & $61(11.5)$ & & \\
\hline \multicolumn{6}{|l|}{$\begin{array}{l}\text { Income } \\
\text { level(Naira) }\end{array}$} \\
\hline$<19,000$ & $325(51.1)$ & $53(50.0)$ & $272(51.3)$ & 6.719 & \\
\hline $20000-49,000$ & $189(29.7)$ & $34(32.1)$ & $155(29.2)$ & & \\
\hline $50000-99,999$ & $94(14.8)$ & $19(17.9)$ & $75(14.2)$ & & \\
\hline $\begin{array}{l}100,000 \text { and } \\
\text { above }\end{array}$ & $28(4.4)$ & $0(0.0)$ & $28(5.3)$ & & \\
\hline \multicolumn{6}{|c|}{ Educational attainment } \\
\hline $\begin{array}{l}\text { No formal ed- } \\
\text { ucation }\end{array}$ & $174(27.4)$ & $30(28.3)$ & $144(27.2)$ & 4.334 & 0.228 \\
\hline Primary & 195(30.7) & $28(26.4)$ & $167(31.5)$ & & \\
\hline Secondary & $202(.31 .8)$ & $41(38.7)$ & $161(30.4)$ & & \\
\hline Tertiary & & $7(6.6)$ & $58(10.9)$ & & \\
\hline
\end{tabular}

Key: $\mathrm{p}<0.05^{*}=$ significant

Self-reported visual defect was found in $47.9 \%$ of controls and $66 \%$ of cases, diagnosis of hypertension among $74.9 \%$ of controls and $85.8 \%$ of cases respectively, a statistically significant difference $(\mathrm{p}<0.05)$. Majority of the study participants neither smoke $(94.3 \%$ cases and $98.1 \%$ controls) nor consume alcohol ( $81.1 \%$ and $87.7 \%)$ while the presence of foamy urine was in only $20.2 \%$ of controls and $14.2 \%$ of cases $(\mathrm{p}>0.05)$ (Table 2$)$.

\section{Measures of Obesity, Twenty four-hour Dietary recall and meal time among participants.}

The use of body mass index (BMI) and waist circumference (WC) as measures of obesity in this study showed that $88.7 \%$ of cases and $77.9 \%$ of controls using BMI, were overweight and obese using their BMI, a statistically significant difference $(\mathrm{p}<0.05)$.
Table 2 Foot care education, social habits and past medical history of study participants

\begin{tabular}{|c|c|c|c|c|c|}
\hline $\begin{array}{l}\text { Characteris- } \\
\text { tics }\end{array}$ & All & $\begin{array}{l}\text { Cases } \\
n=106 \\
(\%)\end{array}$ & $\begin{array}{l}\text { Controls } \\
\mathrm{n}=530 \\
(\%)\end{array}$ & $\chi^{2}$ & $\begin{array}{l}\text { p- } \\
\text { Value }\end{array}$ \\
\hline $\begin{array}{l}\text { Received foot } \\
\text { care education } \\
\text { No } \\
\text { Yes }\end{array}$ & $\begin{array}{l}563(88.5) \\
73(11.5)\end{array}$ & $\begin{array}{l}85(80.27) \\
21(19.8)\end{array}$ & $\begin{array}{c}478(90.2) \\
52(13.6)\end{array}$ & 8.694 & $0.003 *$ \\
\hline $\begin{array}{ll}\text { Walked } & \text { bare } \\
\text { footed } & \\
\text { Yes } & \\
\text { No } & \\
\end{array}$ & $\begin{array}{l}496(78.0) \\
140(22.0) \\
\end{array}$ & $\begin{array}{l}70(66.0) \\
36(34.0) \\
\end{array}$ & $\begin{array}{l}426(80.4) \\
104(19.6) \\
\end{array}$ & 10.580 & $0.001 *$ \\
\hline $\begin{array}{ll}\text { Wearing } & \text { of } \\
\text { tight shoes } & \\
\text { Yes } & \\
\text { No } & \end{array}$ & $\begin{array}{l}554(87.1) \\
82(12.9)\end{array}$ & $\begin{array}{l}86(81.1) \\
20(18.9)\end{array}$ & $\begin{array}{r}468(88.3) \\
62(11.7)\end{array}$ & 4.043 & $0.044 *$ \\
\hline $\begin{array}{l}\text { Inspected foot } \\
\text { for ulcer in the } \\
\text { past } \\
\text { Yes } \\
\text { No }\end{array}$ & $\begin{array}{l}519(81.6) \\
117(18.4)\end{array}$ & $\begin{array}{l}76(71.7) \\
30(28.3)\end{array}$ & $\begin{array}{c}443(83.6) \\
87 \\
(16.4) \\
\end{array}$ & 8.314 & $0.004 *$ \\
\hline $\begin{array}{l}\text { Diagnosed with } \\
\text { Visual defect } \\
\text { Yes } \\
\text { No }\end{array}$ & $\begin{array}{l}334(52.2) \\
302(47.5)\end{array}$ & $\begin{array}{l}70(66.0) \\
36(34.0) \\
\end{array}$ & $\begin{array}{l}264(47.9) \\
266(52.1) \\
\end{array}$ & 9.327 & $0.002 *$ \\
\hline $\begin{array}{l}\text { Presence of } \\
\text { foamy Urine } \\
\text { Yes } \\
\text { No }\end{array}$ & $\begin{array}{l}122(19.2) \\
514(80.8)\end{array}$ & $\begin{array}{l}15(14.2) \\
91(85.8)\end{array}$ & $\begin{array}{l}107(20.2) \\
423(79.8)\end{array}$ & 2.077 & 0.150 \\
\hline $\begin{array}{l}\text { Diagnosed with } \\
\text { Hypertension } \\
\text { Yes } \\
\text { No }\end{array}$ & $\begin{array}{l}488(76.7) \\
148(23.3)\end{array}$ & $\begin{array}{l}91(85.8) \\
15(14.2)\end{array}$ & $\begin{array}{c}397(74.9) \\
133(25.1)\end{array}$ & 5.925 & $0.015^{*}$ \\
\hline $\begin{array}{l}\text { History of } \\
\text { Smoking } \\
\text { Yes } \\
\text { No } \\
\end{array}$ & $\begin{array}{l}16(2.5) \\
620(97.5) \\
\end{array}$ & $\begin{array}{l}6(5.7) \\
100(94.3)\end{array}$ & $\begin{array}{c}10(1.9) \\
520(98.1)\end{array}$ & 5.129 & $0.024 *$ \\
\hline $\begin{array}{l}\text { History of Al- } \\
\text { cohol } \\
\text { Yes } \\
\text { No }\end{array}$ & $\begin{array}{l}85(13.4) \\
551(86.6)\end{array}$ & $\begin{array}{l}20(18.9) \\
86(81.1)\end{array}$ & $\begin{array}{l}65(12.3) \\
465(87.7)\end{array}$ & 3.327 & 0.068 \\
\hline
\end{tabular}

Key: $\mathrm{p}<0.05^{*}=$ statistically significant

However, use of waist circumference (WC) as measures of obesity was not ( $p>0.05)$. (Table 3 ) Furthermore, 24hour dietary recall of food classes, proportion and timing of meals revealed that most cases, $(73.6 \%$ and $56.2 \%$ of controls) recalled ingesting large proportion carbohydrate meal at breakfast and at dinner $(79.2 \%$ and $65.1 \%$ in controls), a statistically significant difference $(\mathrm{p}<0.05)$.

However, no such difference was noted when large proportion of carbohydrate meal was consumed at lunchtime (67\%vs $63.0 \%$ in controls respectively). ( $\mathrm{p}>0.05$ ) (Table 3). 
Table 3 Measures of Obesity, Twenty four- hour Dietary Intake and time among participants

\begin{tabular}{|c|c|c|c|c|c|}
\hline Characteristics & $\begin{array}{l}\text { All } \\
N=636(\%)\end{array}$ & $\begin{array}{l}\text { Cases } \\
n=106(\%)\end{array}$ & $\begin{array}{l}\text { Controls } \\
\mathrm{n}=530(\%)\end{array}$ & $\chi^{2}$ & p-value \\
\hline $\begin{array}{l}\text { BMI } \\
\text { Underweight }(<19) \\
\text { Normal weight }(19.1-24.9) \\
\text { Overweight }(25-29.9) \\
\text { Obese }(>30) \\
\end{array}$ & $\begin{array}{l}17(2.67) \\
112(17.6) \\
270(42.5) \\
237(37.3) \\
\end{array}$ & $\begin{array}{r}0(0 \%) \\
12(11.3) \\
46(43.4) \\
48(45.3) \\
\end{array}$ & $\begin{array}{l}17(3.2) \\
100(18.9) \\
224(38.5) \\
189(39.4) \\
\end{array}$ & 8.479 & $0.037 *$ \\
\hline $\begin{array}{l}\text { Waist Circumference (Male) } \\
<\mathbf{9 4} \\
\mathbf{9 4 - 1 0 1} \\
>\mathbf{1 0 3} \\
\end{array}$ & $\begin{array}{l}61(9.6) \\
46(7.2) \\
32(5.0) \\
\end{array}$ & $\begin{array}{c}10(38.5) \\
9(34.6) \\
7(26.9) \\
\end{array}$ & $\begin{array}{l}51(45.1) \\
37(32.7) \\
25(22.1) \\
\end{array}$ & 0.448 & 0.799 \\
\hline $\begin{array}{l}\text { Waist Circumference (Female) } \\
<\mathbf{8 0} \\
\mathbf{8 1 - 8 7} \\
>\mathbf{8 7} \\
\end{array}$ & $\begin{array}{c}143(29.2) \\
0(0.0) \\
354(55.7) \\
\end{array}$ & $\begin{array}{c}29(36.3) \\
0(0.0) \\
51(63.7) \\
\end{array}$ & $\begin{array}{c}114(27.3) \\
0(0.0) \\
303(72.7) \\
\end{array}$ & 2.601 & 0.107 \\
\hline $\begin{array}{l}24 \mathrm{hr} \text { Diet Recall/Meal Time } \\
\text { Morning/Breakfast } \\
\text { Carbohydrates } \\
\text { Protein } \\
\text { Mixed } \\
\end{array}$ & $\begin{array}{r}376(59.1) \\
97(15.3) \\
163(25.6) \\
\end{array}$ & $\begin{array}{l}78(73.6) \\
17(16.0) \\
11(10.4) \\
\end{array}$ & $\begin{array}{r}298(56.2) \\
80(15.1) \\
152(28.7) \\
\end{array}$ & 16.098 & $0.0001 *$ \\
\hline $\begin{array}{l}\text { Afternoon/Lunch } \\
\text { Carbohydrates } \\
\text { Protein } \\
\text { Mixed } \\
\end{array}$ & $\begin{array}{c}405(63.7) \\
119(18.7) \\
112(17.6) \\
\end{array}$ & $\begin{array}{l}71(67.0) \\
14(13.2) \\
21(19.8) \\
\end{array}$ & $\begin{array}{r}334(63.0) \\
105(19.8) \\
91(17.2) \\
\end{array}$ & 2.627 & 0.269 \\
\hline $\begin{array}{l}\text { Night/Dinner } \\
\text { Carbohydrate } \\
\text { Protein } \\
\text { Mixed } \\
\end{array}$ & $\begin{array}{r}429(67.4) \\
96(15.1) \\
111(17.5) \\
\end{array}$ & $\begin{array}{c}84(79.2) \\
6(5.7) \\
16(15.1) \\
\end{array}$ & $\begin{array}{c}345(65.1) \\
90(17.0 \\
95(17.9) \\
\end{array}$ & 10.528 & $0.005 *$ \\
\hline
\end{tabular}

$\mathrm{p}<0.05^{*}=$ statistically significant

All study variables except presence of foamy urine and history of alcohol intake predicted risk of developing DFU (Table 4). Those who did not receive foot care education were twice more likely to develop DFU compared with those who received foot care education $(\mathrm{OR}=2.27$; $\mathrm{CI}=1.3014-3.9632 ; p<0.05)$ and being diag nosed with hypertension, visual defect and history of smoking were 2.03, 1.96 and 3.12 times more likely to develop DFU compared with those who were not so diagnosed. Those who did not walk bare footed, tight shoes and inspected foot for ulcer were less likely to develop DFU.

Table 4 Regression analysis of study variables as predictors of DFU

\begin{tabular}{|lccccc|}
\hline Variable & Coeff. & SE & $P$-value & OR & $95 \% \mathrm{CI}(\mathrm{OR})$ \\
\hline Received foot care education & 0.8202 & 0.2841 & $0.0039^{*}$ & 2.2710 & $1.3014-3.9632$ \\
Walked bare footed & -0.7451 & 0.2324 & $0.0013^{*}$ & 0.4747 & $0.3010-0.7486$ \\
Wore tight shoes & -0.5627 & 0.2827 & $0.0465^{*}$ & 0.5697 & $0.3274-0.9913$ \\
Inspected foot for ulcer & & & & & \\
in the past & -0.6981 & 0.2454 & $0.0045^{*}$ & 0.4975 & $0.3075-0.8049$ \\
Diagnosed with Visual defect & 0.6725 & 0.2227 & $0.0025^{*}$ & 1.9592 & $1.2661-3.0316$ \\
Presence of foamy Urine & -0.4283 & 0.2989 & 0.1520 & 0.6516 & $0.3627-1.1708$ \\
Diagnosed with Hypertension & 0.7092 & 0.2961 & $0.0166^{*}$ & 2.0324 & $1.1375-3.6314$ \\
History of Smoking & 1.1378 & 0.5278 & $0.0311^{*}$ & 3.1200 & $1.1089-8.7787$ \\
History of Alcohol & 0.5090 & 0.2814 & 0.0704 & 1.6637 & $0.9585-2.8878$ \\
& & & & & \\
\hline
\end{tabular}

\section{DISCUSSION}

About fifty percent of all diabetes-related admissions are due to diabetic foot problems, an estimated $25 \%$ of PLWD will develop problems of diabetic foot (DF) during a lifetime and between $5 \%$ and $15 \%$ will be treated for foot problems and amputation. ${ }^{12}$
Our study evaluated demographic characteristics, foot care education, past medical history, social and dietary habits of PLWD as risk factors for DFU. Over the years, research on clinical and laboratory parameters that predispose and are associated with DFU among PLWD had taken center stage with little attention paid to patients' exposure as other possible risk factors. , $^{2,10,23}$ 
In this study, the demographic characteristics of participants, occupation, income level and educational attainment were neither different between cases and controls nor predictive of DFU though age group and ethnicity were contrary to available reports from Lagos and BeninCity in Nigeria with reported positive association of socio-economic status with DFU..$^{23,24}$ This may be consequent on the generally prevailing low educational attainment, occupation and earning power among this study population who most times will engage in lifestyle habits averse to good health and attend healthcare facilities staffed by healthcare professionals with little or no postgraduate exposure or training in diabetes care. ${ }^{13,17}$ There is therefore the need for continuous medical education of medical practitioners entrusted with the care of diabetes at the secondary health care level.

A study at the University of Benin Teaching Hospital (UBTH) on risk factors, ulcer grade, and management outcome of DFU reported gender prevalence contrasting with our study finding though with similarity in age bracket, socio-economic status, obesity and lack of foot care education. Other established clinical and laboratory characteristics not part of our study design include DM neuropathy, glycaemic control, foot deformities and peripheral vascular disease, lending support to a multi factorial aetiology for DFU. ${ }^{24}$ Added to these are late presentation to hospital often times due to patients' ignorance and lack of understanding of diabetes, paucity of knowledge of diabetes self-care, funds for hospital management due to economic status and fear of limb amputation if they came to the hospital with lack of prompt referral to trained Diabetes care specialists. ${ }^{22}$

In this study, respondents without foot care education, walking bare footed, diagnosis of visual defect show significant association and prediction with development of diabetic foot ulcers similar to the report of Ogbera and Edo. ${ }^{21,}{ }^{24}$ Factors like diagnosis of hypertension and smoking are established as risk factors for non-communicable diseases- peripheral vascular disease, stroke, coronary heart disease and diabetes, DFU and its progression $^{23,24,25}$ Ill-fitting footwear with background of peripheral neuropathy, puncture wounds, thermal injury from application of hot compress to insensate (numb) feet are other preventable events preceding DFU. Education and increased awareness on avoiding these lifestyle habits should form cornerstone for diabetes management aimed to reduce adverse outcome. ${ }^{9,10,12}$ It is noteworthy that the average monthly admission for DFU within this study period was higher during the dry/harmattan season of December to March.

This may probably be because then, patients will likely walk bare-footed (both out and indoors) increasing the risk of puncture injuries.
A similar finding of increased occurrence of DFU during the harmattan season had been reported. ${ }^{26}$ Our study revealed association between presence of foot ulcers, BMI and intake of large carbohydrate meal at breakfast and dinner.

This may be predicated on the high glycaemic index (GI) of such meals with surge in blood glucose level within 90 minutes of ingestion intended to provide energy needed for heavy manual work in most of study participants with low educational attainment, earning power and socioeconomic class. Such blood glucose surge is as detrimental as is chronic and persistent hyperglycaemia. ${ }^{13}$ Carbohydrates are important nutrient to monitor in diabetics since they increase blood glucose the most.

For persons with diabetes, dietary recommendation is in eating a consistently modified carbohydrate diet and American Diabetes Association advice that monitoring carbohydrate intake either by carbohydrate counting or experience-based estimation remain a key strategy in achieving glycaemic control. Report from the University of Michigan Diabetes center also emphasizes the importance of eating vegetables. ${ }^{27}$ This practice will improve clinic attendance and medication compliance consequent on financial ability. ${ }^{22,24}$

\section{CONCLUSION}

Poor patient education on foot care, visual impairment, hypertension, obesity, smoking and alcohol use and inappropriately large carbohydrate meal at breakfast and dinner are associated with development of diabetic foot ulcers and that socio-economic status was not associated.

\section{ACKNOWLEDGEMENT}

The authors wish to acknowledge the cooperation and support of the Chief Consultant, Nursing Staff and Health Information Officers of the Medical Outpatient Clinic, General Hospital Marina, Lagos.

\section{REFERENCES}

1. Boulton AJM. The diabetic foot: from art to science. Diabetologia 2004; 47: 1343-53.

2. Eregie A, Edo AE. Factors associated with diabetic foot ulcers in Benin - City, Nigeria. Niger Med Journal. 2008; 49(1): 9-11.

3. Metelko Z, Brkljacić Crkvencić N. Prevention of diabetic foot. Acta Med. Croatica. 2013; 67 Suppl 1:35-44.

4. Adeloye D, Ige J.O, Aderemi A.V, Adeleye N, Amoo E O, Auta A. et al., 'Estimating the prevalence, hospitalization and mortality from type 2 diabetes mellitus in Nigeria: a systematic review and meta-analysis', BMJ Open 7, 2017, e015424.. 
5. Akanji AO, Adetuyibi A. The pattern of presentation of foot lesions in Nigerian diabetic patients. West Afr J Med 1990; 9: 1-5.

6. Cavanagh P, Attinger C, Abbas Z, et al. Cost of treating diabetic foot ulcers in five different countries. Diabetes Metab Res Rev 2012; 28 Suppl 1:10711.

7. Almobarak AO, Awadalla H, Osman M, Ahmed MH. Prevalence of diabetic foot ulceration and associated risk factors: an old and still major public health problem in Khartoum, Sudan? Ann Transl Med. 2017; 5(17): 340

8. Abbott, CA, Carrington AL, Ashe H, Bath S, Every LC, Griffiths J, et al. The North-West Diabetes Foot Care Study: incidence of, and risk factors for, new diabetic foot ulceration in a community-based patient cohort. Diabet Med 2002; 19 (5): 377-84.

9. Boulton AJM, Vileikyte L, Kirsner RS. Neuropathic diabetic foot ulcers. New Eng. J Med. 2004; 251: 4855

10. Monteiro-Soares M, Boyko EJ, Ribeiro J, Ribeiro I, Dinis-Ribeiro M. Predictive factors for diabetic foot ulceration: a systematic review. Diabetes Metab Res Rev. 2012; 28 (7):574-600.

11. Crawford F, Inkster M, Kleijnen J, Fahey T. Predicting foot ulcers in patients with diabetes: a systematic review and meta-analysis. QJM. 2007; 100 (2): 6586.

12. Lipsky BA, Berendt AR, Deery HG, Embil JM, Joseph WS, Karchmer AW, LeFrock JL, Lew DP, Mader JT, Norden C, Tan JS; Infectious Diseases Society of America; Diagnosis and treatment of diabetic foot infections. Plast Reconstr Surg. 2006; 117 (7 Suppl):212S-238S.

13. American Diabetes Association. Standards of Medical Care in Diabetes - 2014. Diabetes Care. 2014; 37 Suppl 1: S14-80.

14. Vuorisalo S1, Venermo M, Lepäntalo M. Treatment of diabetic foot ulcers. J Cardiovasc Surg (Torino). 2009; 50 (3): 275-91.

15. Ogbera AO, Fasanmade O, Ohwovoriole AE, Adediran O. Assessment of the disease burden of foot ulcers in patients with diabetes mellitus attending a teaching hospital in Lagos Nigeria. Int J Lower Extrem Wounds 2006; 5(4): 244-49.

16. Barg FK, Cronholm PF, Easley EE, Davis T, Hampton M, Malay DS, Donohue C, Song J, Thom SR, Margolis DJ. A qualitative study of the experience of lower extremity wounds and amputations among people with diabetes in Philadelphia. Wound Repair
Regen. 2017 8. doi: 10.1111/wrr.12593. [Epub ahead of print]

17. International Diabetes Federation Atlas 7 edition 2015; Executive summary, Diabetes: A global emergency. Available from:

https://www.diabetesatlas.org Accessed on 17 September 2017.

18. Armstrong DG1, Lavery LA. Diabetic foot ulcers: prevention, diagnosis and classification. Am Fam Physician. 1998; 57 (6): 1325-32, 1337-8.

19. Odusan O. Diabetic Foot Ulcers: Improving outcome. Nigerian Endocrine Practice 2010; 4 (2): 1118

20. Saleem S1, Hayat N1, Ahmed I1, Ahmed T1, Rehan AG1. Risk factors associated with poor outcome in diabetic foot ulcer patients Turk J Med Sci. 2017; 47 (3): 826-831.

21. Ogbera AO, Adedotun A, Fasanmade OA, Ohwovoriole AE, Ajani M. The foot at risk in Nigerians with Diabetes Mellitus-The Nigerian Scenario. Int J Endocrinol Metab 2005; 4: 165-73.

22 Odusan O, Amoran OE, Salami O. Prevalence and pattern of Diabetic Foot Ulcers among adults with Diabetes mellitus in a secondary health care facility in Lagos, Nigeria. Annals of Health Research 2017; 3 (2): 98 - 104

23 Ekpebegh CO, Iwuala SO, Fasanmade OA, Ogbera AO, Igumbor E, Ohwovoriole AE. Diabetes foot ulcer in a Nigerian teaching hospital: in-hospital mortality in relation to presenting demographic clinical and laboratory features. Int Wound J 2009; 6 (5): 281-5

24 Andrew E Edo, Gloria O Edo, Ignatius U Ezeani. Risk factors, ulcer grade and management outcome of diabetic foot ulcers in a tropical tertiary care hospital, Benin Nigeria. Niger Med J. 2013; 54 (1): 59-63

25 Abbott CA, Garrow AP, Carrington AL, Morris J, Van Ross ER, Boulton AJ; North-West diabetes foot care study: Foot ulcer risk is lower in SouthAsian and african-Caribbean compared with European diabetic patients in the U.K. Diabetes Care. 2005; 28 (8): 1869-75.

26 Akanji AO. Two unusual predisposing factors for diabetic pedal ulceration in Nigerians. Trop Geogr Med. 1990; 42 (1): 83-6.

27 University of Michigan Comprehensive Diabetes Center. Why is it important to eat vegetables? http://www.med.umich.edu/1libr/MEND/DiabetesNon Carb Foods. 